\title{
Faktor-Faktor yang Mempengaruhi Penghindaran Pajak
}

\author{
Indah Novriyanti ${ }^{\mathrm{a}}$, and Winanda Wahana Warga Dalam ${ }^{\mathrm{b}, *}$ \\ ${ }^{a}$ Program Studi Akuntansi Manajerial, Politeknik Negeri Batam, indahnov28@gmail.com, Indonesia \\ ${ }^{b}$ Program Studi Akuntansi Manajerial, Politeknik Negeri Batam,winanda@polibatam.com, Indonesia
}

\begin{abstract}
Non-compliance of taxpayers triggers a reduction in the value of taxes received by the state. The results of the tax amnesty program prove that there are still many taxpayers who deliberately do not pay taxes to the state treasury. The purpos e of this study is to examine the factors that influence tax avoidance. The object of this research is a manufacturing company, registered with IDX in 2013-2017. The data used in this study are secondary data. The samples used in this study were 240 companies. Analysis technique uses panel data regression analysis. The results of this study are profitability has a positive effect and leverage has a negative effect on tax avoidance. While the size of the company, the intensity of fixed assets and sales growth does not affect tax avoidance.
\end{abstract}

Keywords: tax avoidance, Tax, Manufacturing

${ }^{*}$ Corresponding author. E-mail: winanda@polibatam.ac.id 


\section{Pendahuluan}

Pajak adalah sumber pendapatan bagi negara yang paling berkontribusi dalam penyelenggaraan kegiatan bernegara. Warga negara Indonesia yang berstatus wajib pajak diharuskan membayar pajak ke kas negara. Dalam pelaksanaannya, wajib pajak dan pemerintah tidak memiliki keselarasan tujuan. Bagi wajib pajak, pajak yang dibayarkan adalah biaya yang bisa memperkecil laba bersih. Namun bagi pemerintah pajak adalah sumber pembiayaan negara yang dibutuhkan dalam pembangunan nasional. Karena ketidakselarasan tujuan tersebut, wajib pajak cenderung melakukan upaya untuk meminimalkan biaya pajak dengan melakukan tindakan penghindaran pajak.

Program pengampunan pajak (tax amnesty) yang diselenggarakan pemerintah selama 2 tahun yaitu tahun 2016 dan 2017 dilakukan melalui beberapa periode menghasilkan nilai yang cukup signifikan yaitu sebesar Rp 3.460,80 triliun di tahun 2016 dan Rp 4.884,26 triliun di tahun 2017. Dapat dikatakan bahwa terdapat banyak wajib pajak di Indonesia yang dengan sengaja menerapkan tindakan penghindaran pajak yang mengakibatkan pendapatan negara menjadi berkurang. Dilihat dari laporan tahunan Direktorat Jendral Pajak, pajak yang diterima negara pada tahun pada tahun 2016 sebesar Rp 1.105,97 triliun atau 81,61\% dari target dan pada tahun 2017 sebesar Rp 1.151,03 triliun atau 89,67\% dari target (www.pajak.go.id). Tindakan penghindaran pajak yang dilakukan oleh wajib pajak dapat secara ilegal maupun legal. Secara ilegal yaitu dengan tax evasion sedangkan tindakan secara legal dengan tax avoidance. Tax avoidance adalah upaya penghindaran pajak secara legal karena tidak bertentangan dengan ketentuan perpajakan karena metode dan teknik yang digunakan dengan memanfaatkan kelemahan-kelemahan yang ada dalam undang-undang dan peraturan perpajakan untuk dapat memperkecil jumlah pajak terutang (Pohan, 2016). Tindakan ini menjadi kendala bagi pemerintah untuk melaksanakan pembangunan karena setiap tahunnya nilai pajak yang dianggarkan tidak sesuai dengan realisasinya. Pemerintah berharap semua wajib pajak menyetorkan pajaknya ke kas negara secara benar dan jujur.

Salah satu faktor yang menjadi penyebab perusahaan melakukan tindakan penghindaran pajak adalah profitabilitas yang dapat dilihat dari Return on Asets (ROA). Tingkat profitabilitas perusahaan yang semakin tinggi mempengaruhi tingginya tingkat penghindaran pajak. Hal ini terjadi karena perusahaan yang memiliki laba besar akan lebih mudah memanfaatkan celah dalam mengelola biaya pajaknya (Dewinta \& Setiawan, 2016). Faktor selanjutnya adalah leverage yang merupakan rasio pengukur seberapa jauh perusahaan menggunakan hutang dalam membiayai aktivitas operasinya. Tingginya tingkat leverage akan mempengaruhi tingginya jumlah pendanaan dari utang yang menimbulkan beban bunga dan beban bunga akan mempengaruhi berkurangnya biaya pajak (Dharma \& Ardiana, 2016).

Ukuran perusahaan menjadi faktor ketiga dalam perusahaan untuk melakukan tindakan penghindaran pajak. Ukuran perusahaan yang semakin besar akan mempengaruhi tingginya tingkat penghindaran pajak agar mencapai penghematan beban pajak yang maksimal (Darmawan \& Sukartha, 2014). Faktor keempat adalah intensitas aset tetap. Semakin tinggi aset tetap akan mempengaruhi biaya depresiasi yang semakin tinggi sehingga nilai pajak yang dibayar berkurang. Berarti semakin tinggi jumlah aset, perusahaan cenderung tidak melakukan penghindaran pajak (Adisamartha \& Noviari, 2015). Faktor yang terakhir adalah pertumbuhan penjualan. Peningkatan pertumbuhan penjualan akan membuat perusahaan mendapat profit yang tinggi jadi perusahaan akan melakukan praktik penghindaran pajak (Dewinta \& Setiawan, 2016).

Beberapa riset sebelumnya yang menggunakan faktor-faktor diatas untuk melihat pengaruhnya terhadap praktik penghindaran pajak memiliki hasil yang berbeda. Penelitian oleh Dewinta \& Setiawan (2016), Darmawan \& Sukartha (2014) dan Puspita \& Febrianti (2017) menunjukkan terdapat pengaruh profitabilitas terhadap penghindaran pajak. Penelitian mengenai pengaruh leverage terhadap penghindaran pajak dilakukan oleh Dharma \& Ardiana (2016) menunjukkan bahwa leverage berpengaruh negatif terhadap penghindaran pajak, sedangkan penelitian Darmawan \& Sukartha (2014), Dewinta \& Setiawan (2016), Irianto, Sudibyo, \& Wafirli (2017) dan Hidayat (2018) menunjukkan leverage tidak berpengaruh terhadap penghindaran pajak.

Penelitian Dewinta \& Setiawan (2016), Dharma \& Ardiana (2016) dan Irianto, Sudibyo, \& Wafirli (2017) menunjukkan ukuran perusahaan berpengaruh positif terhadap penghindaran pajak sedangkan Muzakki \& Darsono (2015) dan Dharma \& Ardiana (2016) menyatakan intensitas aset tetap berpengaruh negatif terhadap penghindaran pajak. Pertumbuhan penjualan didukung oleh penelitian Puspita \& Febrianti (2017) serta penelitian Dewinta \& Setiawan 
(2016) yang menyatakan adanya pengaruh positif pertumbuhan penjualan terhadap penghindaran pajak. Penelitian yang dilakukan Permata, Nurlaela, \& Mastoh W (2018) menunjukkan bahwa pertumbuhan penjualan tidak berpengaruh terhadap penghindaran pajak.

Penelitian ini mengacu pada penelitian sebelumnya yang dilakukan Irianto, Sudibyo, \& Wafirli (2017) yang meneliti pengaruh profitabilitas, leverage, ukuran perusahaan dan intensitas modal terhadap penghindaran pajak pada perusahaan manufaktur yang terdaftar di BEI periode 2013-2015. Perbedaan dalam penelitian ini dengan penelitian sebelumnya yaitu menggunakan tahun terbaru 20122017 dengan tujuan untuk memberi informasi terbaru bagi pengguna laporan keuangan serta penambahan variabel independen berupa pertumbuhan penjualan yang mengacu pada penelitian Permata, Nurlaela, \& Mastoh W (2018). Penelitian tersebut dilakukan terhadap sektor industri dan kimia yang terdaftar di BEI tahun 2012-2016.

Berdasarkan uraian diatas, maka penulis tertarik untuk meneliti faktor-faktor yang mempengaruhi penghindaran pajak dengan judul "Pengaruh Profitabilitas, Leverage, Ukuran Perusahaan, Intensitas Aset Tetap dan Pertumbuhan Penjualan Terhadap Penghindaran Pajak"

\section{Kerangka Teori dan Pengembangan Hipotesis}

\section{Kerangka Teori}

\section{Teori Agensi}

Teori ini menjelaskan mengenai hubungan antara pemegang saham sebagai principal dan manajemen sebagai agen. Dimana dimana prinsipal mempercayakan pengelolaan operasi perusahaan kepada agen sehingga agen memiliki tanggung jawab penuh atas pekerjaannya terhadap prinsipal. Hubungan keagenan ini membuat agen terikat untuk selalu membuat keputusan terbaik demi kepentingan prinsipal. Dalam praktiknya tidak selalu berjalan dengan yang diharapkan kedua belah pihak sehingga menimbulkan masalah yaitu asymmetry information. Teori ini mengatakan bahwa pihak agen lebih banyak memiliki informasi mengenai kondisi actual internal perusahaan dibandingan pihak principal Hal tersebut memicu adanya perbedaan kepentingan yang menyebabkan ketidakefesienan informasi yang diperoleh (Jensen \& Meckling 1976).

\section{Penghindaran Pajak (Tax Avoidance)}

Penghindaran pajak adalah menghindari pajak yang harus dibayarkan agar terlihat lebih kecil dari yang harus dibayarkan semestinya namun tidak ada peraturan pajak yang dilanggar. Walaupun secara peraturan pajak tidak dlilanggar namun dari pihak kantor pajak kurang baik karena dapat menurunkan pendapatan pajak pemerintah. Pemerintah sendiri mengetahui bahwa perusahaan yang secara legal dikenakan pajak berusaha untuk menghindari pajak dengan berbagai cara agar pejak yang dikenakan lebih kecil.

\section{Profitabilitas}

Menurut Kasmir (2014) pengertian rasio profitabilitas adalah kemampuan perusahaan dalam menghasilkan laba atau keuntungan. Penelitian ini menggunakan return on Asset (ROA) yaitu jumlah laba dibagi dengan jumlah aktiva. menurut (Kasmir, 2014). Semakin tinggi rasio ROA semakin effisien perusahaan menggunakan assetnya dalam menghasilkan laba perusahaan.

\section{Leverage}

Hanafi \& Halim (2016) mengatakan bahwa leverage menilai memenuhi kewajiban jangka Panjang. Perusahaan yang sehat adalah perusahaan yang total hutangnya menilai tidak lebih besar dari pada total assetnya. Leverage membandingkan total hutang jangkan panjangnya terhadap total asset, rasio ini digunakan manajemen perusahaan untuk mengetahui apakah dilakukan pendanaan dilakukan oleh perusahaan tesebut.

\section{Ukuran Perusahaan}

Ukuran perusahaan yand dimaksud adalah besar 
kecilnya perusahaan. besar kecilnya perusahaan ditentukan oleh total penjualan, total asset, dan tingkat rata-rata tingkat penjualan (Seftianne \& Handayani, 2011). Dalam penelitian ini ukuran perusahaan menggunakan total asset tolak ukurnya.

\section{Intensitas Aset Tetap}

Insensitas asset tetap perusahaan menggambarkan biaya depresiasi perusahaan. biaya depresiasi tersebut berhubungan dengan asset tetap. Asset tetap ini adalah salah satu bentuk investasi perusahaan yang dilakukan untuk menghasilkan laba. Laba ini akan mempengaruhi jumlah pajak yang akan dikenakan. Maka besar kecilnya laba akan dipengaruhi metode depresiasi yang digunakan perusahaan. apabila depresiasi besar maka laba kena pajak perusahaan semakin kecil, dan sebaliknya apabila depresiasi nya kecil maka lama kena pajak perusahaan akan semakin besar.

\section{Pertumbuhan Penjualan}

Menurut Widarjo \& Setiawan (2009) pertumbuhan penjualan mempresentasikan kemampuan perusahaan dalam menjalankan target dan strateginya. Perusahaan yang berhasil menjalankan target dan strateginya maka perusahaan akan mendapatkan profit yang lebih tinggi, semakin tinggi profit yang didapat oleh perusahaan maka perusahaan akan cenderung semakin tinggi untuk melakukan penghindaran pajak, hal ini dikarenakan semakin tinggi profit akan menghasilkan pajak terhutangnya yang juga tinggi.

\section{Pengembangan Hipotesis}

\section{Pengaruh Profitabilitas terhadap Penghindaran Pajak}

Menurut Kasmir (2014) mengatakan bahwa profitabilitas menilai perusahaan apakah dapat mendapatkan keuntungan atau laba pada satu periode akuntansi. Rasio ini memberikan ukuran sebuah efektivitas manajemen perusahaan yang ditujukkan dengan laba yang dihasilkan.
Saat profit perusahaan tinggi, biaya pajak yang dibayarkan semakin besar. Hal ini berkaitan dengan konflik kepentingan dimana membuat agen berusaha untuk meminimalkan biaya pajak agar tidak mengurangi kompensasi kinerja agen dengan memanfaatkan biaya depresiasi sebagai pengurang laba kena pajak. Tindakan tersebut dilakukan agar profit perusahaan tetap stabil dan pihak principal merasa puas atas kinerja agen.

Dapat dilihat dari hasil penelitian terdahulu yang dilakukan Dewinta \& Setiawan (2016) menunjukkan hasil bahwa ROA berpengaruh terhadap penghindaran pajak. Hal ini juga didukung oleh penelitian yang dilakukan Puspita \& Febrianti (2017) yang menunjukkan hasil yang sama. Menurut uraian tersebut dapat dilihat bahwa semakin tinggi profitabilitas suatu perusahaan, maka semakin meningkat pula keinginan perusahaan untuk melakukan tindakan penghindaran pajak. Jadi penulis menyimpulkan hipotesis pertama yaitu :

H1: Profitabilitas berpengaruh positif terhadap penghindaran pajak

\section{Pengaruh Leverage terhadap Penghindaran Pajak}

Perusahaan menggunakan leverage dengan tujuan mendapatkan keuntungan yang lebih besar yang akan berpengaruh ke pemegang saham. Tingkat leverage yang tinggi di perusahaan akan mengurangi biaya pajaknya karena leverage erat hubungannya dengan biaya bunga yang akan memperkecil nilai laba kena pajak. Berdasarkan teori akuntansi positif, semakin tinggi hubungan perusahaan dengan pihak kreditur maka perusahaan akan menjaga laba periode berjalan dengan mengalokasikan laba periode mendatang ke laba periode berjalan. Jadi dengan tingkat hutang yang semakin tinggi, upaya perusahaan untuk melakukan penghindaran pajak semakin kecil. Dapat dilihat hubungan antara leverage dan penghindaran pajak perusahaan dalam penelitian Dharma \& Ardiana (2016) menunjukkan bahwa leverage berpengaruh negatif terhadap penghindaran pajak. Dari hasil penelitian tersebut, penulis menyimpulkan hipotesis kedua yang akan diajukan adalah sebagai berikut : 
H2: Leverage berpengaruh negatif terhadap penghindaran pajak

\section{Pengaruh Ukuran Perusahaan terhadap Penghindaran Pajak}

Ukuran perusahaan merupakan skala perbandingan antara perusahaan besar dan perusahaan kecil. Dalam penelitian ini ukuran perusahaan ditentukan oleh nilai asetnya. Berdasarakan teori agensi, agen akan memanfaatkan sumber daya yang dimiliki perusahaan sebagai peluang dalam meningkatkan keuntungan yang lebih besar, namun untung yang besar akan mempengaruhi biaya pajak yang semakin besar pula. Hal itu mendorong perusahaan untuk melakukan tindakan penghindaran pajak. Penelitian sebelumnya yang dilakukan Darmawan \& Sukartha (2014) dan Irianto, Sudibyo, \& Wafirli (2017) serta Dewinta \& Setiawan (2016) membuktikan bahwa ukuran perusahaan memiliki pengaruh positif terhadap tindakan penghindaran pajak. Dari uraian tersebut, hipotesis ketiga yang penulis ajukan adalah:

H3: Ukuran perusahaan berpengaruh positif terhadap penghindaran pajak

\section{Pengaruh Intensitas Aset Tetap terhadap Penghindaran Pajak}

Rasio intensitas aset tetap menggambarkan hubungan antara aktiva tetap dan saham perusahaan. Perusahaan berusaha untuk mendapatkan keuntungan dari berbagai sisi perusahaan, salah satunya aset. Perusahaan yang memiliki aset yang banyak akan mempengaruhi biaya depresiasinya, sehingga biaya depresiasi dapat mengurangi biaya pajak yang akan dibayar. Jika dihubungkan dengan teori agensi, agen cenderung memilih peluang untuk meningkatkan laba perusahaan yang tidak beresiko. Investasi berupa aset menjadi salah satu pilihan karena penggunaan aset yang semakin tinggi akan menghasilkan penjualan yang tinggi dan berpengaruh terhadap keuntungan yang diterima. Laba tinggi akan mempengaruhi nilai pajak yang dibayar, namun hal ini dapat dicegah dengan pemanfaatan biaya depresiasi dari aset yang dimiliki. Jadi, tingkat investasi terhadap aset yang tinggi membuat semakin kecil usaha perusahaan untuk melakukan penghindaran pajak. Penelitian yang dilakukan Adisamartha \& Noviari (2015) yang menunjukkan bahwa intensitas aset tetap perusahaan berpengaruh negatif terhadap tindakan penghindaran pajak. Jadi penulis menyimpulkan hipotesis keempat sebagai berikut:

H4 : Intensitas aset tetap berpengaruh negatif terhadap penghindaran pajak

Pengaruh Pertumbuhan Penjualan terhadap Penghindaran Pajak

Pertumbuhan penjualan menunjukkan peningkatan laba dari suatu penjualan yang dihasilkan. Pertumbuhan penjualan yang meningkat akan mempengaruhi peningkatan operasi perusahaan sehingga menghasilkan profit yang semakin tinggi. Berdasarkan dengan teori agensi, agen akan memperoleh laba yang besar apabila pertumbuhan penjualan meningkat namun akan mempengaruhi nilai pajak yang akan dibayarkan sehingga agen akan berusaha meminimalkan nilai pajak perusahaan untuk pelaporan kepada pihak prinsipal. Hal ini didukung oleh penelitian Dewinta \& Setiawan (2016) yang menunjukkan bahwa pertumbuhan penjualan berpengaruh positif terhadap penghindaran pajak. Penulis menyimpulkan hipotesis kelima yang diajukan sebagai berikut :

H5: Pertumbuhan penjualan berpengaruh positif terhadap penghindaran pajak

Berdasarkan penjelasan diatas maka model penelitian sebagai berikut:

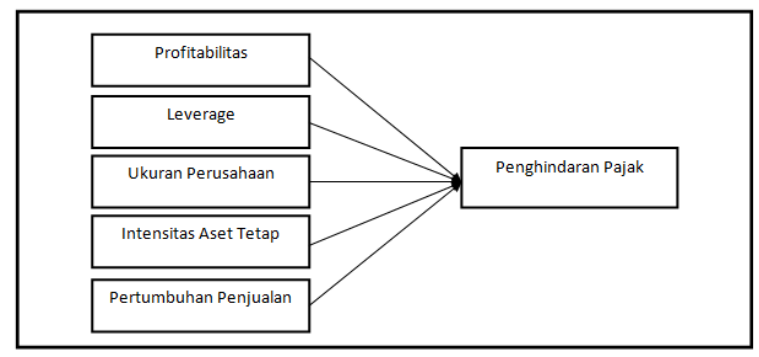

Gambar 1. Model Penelitian Sumber: Penulis 


\section{Metode Penelitian}

Penelitian ini adalah merupakan penelitian kuantitatif yang menggunakan data sekunder, yaitu dengan cara mengumpulkan dan menganalisa aa laporan keuangan perusahaan yang terdaftar di IDX (Indonesian stock exchange) tahun 2013-2017. Variabel dependennya adalah penghindaran pajak dan variable idependennya adalah profitabilitas, leverage, ukuran perusahaan, intensitas asset tetapdan pertumbuhan penjualan. Berikut definisi operasional variabel penelitian ini.

\section{Penghindaran Pajak}

Variabel dependen dalam penelitian ini adalah penghindaran pajak yang dihitung melalui Cash ETR dengan tujuan melihat kas yang dibayarkan untuk pajak yaitu dapat dilihat dalam laporan arus kas. Menurut Goh, Lee, Lim, \& Shevlin (2013) rumus menghitung CETR sebagai berikut:

$$
\text { Cash ETR }=\frac{\text { Kas Pajak yang Dibayar }}{\text { Laba sebelum Pajak }}
$$

\section{Profitabilitas}

Profitabilitas sebagai variabel independen dalam penelitian ini diukur menggunakan rasio Return on Asets (ROA) yang merupakan pengukuran rasio berdasarkan kemampuan perusahaan untuk menghasilkan profit. Menurut Brigham \& Houston (2001) rumus menghitung ROA sebagai berikut :

$$
\text { Return On Asset }=\frac{\text { Laba Bersih }}{\text { Total Asset }}
$$

\section{Leverage}

Variabel leverage dalam penelitian ini diukur menggunakan proksi debt to assets ratio. Rasio ini membandingkan total hutang dibagi dengan total asset, hal ini menunjukkan kemampunan perusahaan dalam membayar hutang-hutangnya. Menurut Kieso, Weygandt, \& Wardield (2011) rasio leverage dapat dirumuskan sebagai berikut:

$$
\text { Debt to Asset Ratio }=\frac{\text { Total Hutang }}{\text { Total Asset }}
$$

\section{Ukuran Perusahaan}

Menentukan ukuran sebuah perusahaan dapat diukur menggunakan transformasi total aset yang dimiliki perusahaan ke dalam bentuk logaritma natural. Menurut Murhadi (2013) ukuran perusahaan dihitung dengan rumus berikut :

\section{Ukuran Perusahaan=Log Natural Total Asset}

\section{Intensitas Aset Tetap}

Aset merupakan hal penting bagi perusahaan dalam menjalankan operasinya. Menurut Darmadi (2013) rumus intensitas asset tetap adalah hasil pembagian total asset tetap terhadap total asset.

$$
\text { Intensitas Asset Tetap }=\frac{\text { Total Asset Tetap }}{\text { Total Asset }}
$$

\section{Pertumbuhan Penjualan}

Menurut Horne \& Wachowicz (2013), rumus untuk menghitung pertumbuhan penjualan sebagai berikut:

$$
G=\frac{\mathrm{St} 1-(\mathrm{St}-1) \times 100 \%}{\mathrm{St}-1}
$$

Selain itu, data dalam penelitian ini diolah dengan menggunakan Eviews versi 9. Metode Analisa data adalah menggunakan metode statistik deskriptif. Penelitian ini menggunakan menggunakan uji asumsi klasik yand terdiri dari uji dan uji heteroskedastisitas. Pengujian hipotesis pertama sampai hipotesis keenam menggunakan uji t statistik dengan analisis regresi linear berganda, serta melihat bagaimana koefisien determinasi antar variabel. Penelitian ini menggunakan perusahaan yang tercatat di IDX (Indonesian Stock Exchange). Sampel penelitian ini adalah perusahaan manufaktur dengan teknik pengambilan sampel yaitu purposive sampling dengan kreteria:

1. Perusahaan manufaktur yang tercatat di IDX yang tercatat selama 2013 sampai dengan 2017, tidak mengalami delisting dan IPO selama periode penelitian.

2. Data yang digunakan adalah perusahaan yang memiliki data yang lengkap terkait data vaiabel penelitian. 
3. Perusahaan memiliki nilai laba sebelum pajak positif.

4. Perusahaan yang memiliki beban pajak positif dikeluarkan dari sampel.

5. Perusahaan yang digunakan adalah perusahaan yang melaporkan laporan keuangan menggunakan mata uang rupiah

Sementara terkait uji asumsi klasik, Basuki \& Prawoto (2016) menyatakan bahwa uji asumsi klasik yang digunakan dalam regresi linier dengan pendekatan Ordinary Least Squared (OLS) meliputi uji linieritas, autokorelasi, heteroskdastisitas, multikolinieritas dan normalitas. Namun tidak semua uji perlu dilakukan, karena :

a. Model diasumsikan bersifat linier, maka tidak perlu uji linieritas

b. Pada syarat BLUE (Best Linier Unbias Estimator) uji normalitas tidak termasuk didalamnya.

c. Uji autokorelasi hanya dibutuhkan pada data time series.

d. Jika model regresi terdapat lebih dari satu variabel independen maka harus dilakukan uji multikolinearitas

e. Heteroskedastisitas sering terjadi pada data cross section.

\section{Pembahasan}

\section{Deskripsi Sampel Penelitian}

Tabel dibawah ini (tabel 1) menunjukkan statistik deskriptif. Perusahaan go public yang terdaftar di Bursa Efek Indonesia (BEI) selama tahun 2013-2017 merupakan populasi dalam penelitian ini. Namun jumlah tersebut dikurangi dengan kriteria sampel yaitu perusahaan yang termasuk dalam sektor manufaktur sebanyak 165 perusahaan. Perusahaan yang melakukan IPO selama tahun observasi sebanyak 23 perusahaan, perusahaan yang melakukan delisting selama tahun observasi sebanyak 5 perusahaan, perusahaan yang pindah sektor ke non manufaktur sebanyak 2 perusahaan, perusahaan yang menyajikan laporan keuangan tidak dalam satuan rupiah sebanyak 7 perusahaan, dan perusahaan yang memiliki nilai laba sebelum pajak negatif sebanyak 80 perusahaan. Jadi, total sampel yang memenuhi kriteria yang telah ditetapkan sebesar 48 perusahaan per tahun dan jumlah observasi keseluruhan selama periode 2013-2017 adalah 240 perusahaan ( $48 \times 5$ tahun) yang dapat dilihat pada tabel 1 .
Tabel 1

Jumlah Sampel

\begin{tabular}{lc}
\hline \multicolumn{1}{c}{ Indikasi Perusahaan } & Jumlah \\
\hline $\begin{array}{l}\text { Perusahaan manufaktur yang terdaftar di Bursa Efek Indonesia } \\
\text { periode 2013-2017 }\end{array}$ & 165 \\
$\begin{array}{l}\text { Jumlah perusahaan manufaktur yang pindah sektor di Bursa Efek } \\
\text { Indonesia periode 2013-2017 }\end{array}$ & $(2)$ \\
$\begin{array}{l}\text { Perusahaan yang pertama kali terdaftar (IPO) \& Delisting selama } \\
\text { tahun 2013-2017 }\end{array}$ & $(28)$ \\
$\begin{array}{l}\text { Perusahaan yang menggunakan mata uang selain Rupiah (Rp) } \\
\text { Perusahan yang mengalami rugi fiskal selama tahun 2013-2017 }\end{array}$ & $(7)$ \\
\hline Perusahaan yang terpilih menjadi sampel per tahun & $\mathbf{4 8}$ \\
\hline Total Sampel periode 2012-2017 & $\mathbf{2 4 0}$ \\
\hline \hline Sumber: idx.co.id, data diolah
\end{tabular}

Analisis deskriptif merupakan gambaran suatu data yang dilihat dari nilai mean, maximum, minimum, dan standar deviasi. Hasil ini diperoleh berdasarkan data keuangan yang ditentukan oleh penulis yang dapat dilihat pada tabel 2 .

Tabel 2

Statistik Deskriptif

\begin{tabular}{lrrrr}
\hline Variabel & Mean & Maximum & Minimum & Std. Dev \\
\hline CETR & -0.3656 & -0.0220 & -2.6987 & 0.3185 \\
ROA & 0.1066 & 0.6572 & -0.0020 & 0.0967 \\
LEV & 0.3967 & 0.8809 & 0.0837 & 0.1632 \\
SIZE & 21.7460 & 26.4124 & 18.7117 & 1.6559 \\
IAT & 0.4234 & 0.8081 & 0.1001 & 0.1610 \\
GROWTH & 0.0758 & 4.1873 & -0.7599 & 0.6760 \\
Sampel(N) & \multicolumn{2}{c}{240} \\
\hline
\end{tabular}

Keterangan: Tabel ini mempresentasikan hasil uji statistik. Variabel dependen: Cash Effective Tax Rate (CETR). Variabel independen: Return on Assets (ROA), Leverage (LEV), Ukuran Perusahaan (SIZE), Intensitas Aset Tetap (IAT), dan Pertumbuhan Penjualan (Growth).

Sumber: Data yang diolah dengan Eviews 9

Berdasarkan hasil uji statistik deskriptif pada tabel 2, maka dapat diketahui jumlah data yang digunakan dalam penelitian ini adalah 240 data sampel. Variabel dependen berupa penghindaran pajak yang diukur dengan Cash ETR. Cash ETR diukur menggunakan tax payment dibagi dengan laba sebelum pajak dan dikali -1. Rata-rata perusahaan mempunyai total beban pajak sebesar $-36 \%$ dari laba sebelum pajak, beban pajak tertinggi sebesar $(-0,0220)$, beban pajak terendah sebesar $(-2,698)$ dan standar deviasi antara nilai tertinggi dan terendah sebesar 0,3185 .

Variabel independen dalam penelitian ini terdiri atas lima variabel yaitu profitabilitas, leverage, ukuran perusahaan, intensitas asset tetap, dan pertumbuhan penjualan. Rata-rata perusahaan dapat menghasilkan laba bersih sebesar 10\% dari total aset. Laba bersih tertinggi sebesar 0,6572 dari total aset, laba bersih terendah sebesar $(-0,0020)$ dari total aset dan standar deviasi antara nilai tertinggi dan terendah 
sebesar 0,0967. Variabel independen kedua yaitu leverage dengan menggunakan alat ukur debt to asset. Rata-rata perusahaan menggunakan total utang 0,3967 dari total aset. Total utang tertinggi sebesar 0,8809 , total utang terendah sebesar 0,0837 dan standar deviasi antara nilai tertinggi dan terendah sebesar 0,1632 .

Variabel independen ketiga yaitu size dihitung menggunakan logaritma natural aset. Rata-rata ukuran perusahaan sebesar 21,7460 dari total aset. Ukuran perusahaan tertinggi sebesar 26,4124 dari total aset, ukuran perusahaan terendah sebesar 18,7117 dari total aset dan standar deviasi antara nilai tertinggi dan terendah sebesar 1,6559. Variabel independen keempat yaitu intensitas aset tetap. Ratarata perusahaan menggunakan aset tetap sebesar 0,4234 dari total aset. Total aset tetap tertinggi sebesar 0,8081, total aset tetap terendah sebesar 0,1001 dan standar deviasi antara nilai tertinggi dan terendah sebesar 0,1610. Variabel independen kelima yaitu pertumbuhan penjualan diukur menggunakan nilai penjualan bersih periode berjalan dikurang penjualan bersih periode lalu dibagi dengan penjualan bersih periode lalu. Rata-rata pertumbuhan penjualan sebesar 0,0758. Pertumbuhan penjualan tertinggi sebesar 4,1873, pertumbuhan penjualan terendah sebesar $(-0,7599)$ dan standar deviasi antara nilai tertinggi dan terendah sebesar 0,6760.

Berdasarkan uji statistik deskriptif pada tabel diatas, variabel dependen berupa penghindaran pajak yang diukur dengan Cash ETR. Rata-rata perusahaan mempunyai total beban pajak sebesar $-36 \%$ dari laba sebelum pajak, beban pajak tertinggi sebesar (0,0220) oleh PT Ricky Putra Globalindo Tbk. Tahun 2016 dan beban pajak terendah sebesar $(-2,698)$ oleh PT Sepatu Bata Tbk. Tahun 2013 serta standar deviasi antara nilai tertinggi dan terendah sebesar 0,3185. Rata-rata ROA dalam penelitian ini adalah $10 \%$.

Laba bersih tertinggi sebesar 0,6572 dari total aset oleh PT Multi Bintang Indonesia Tbk. tahun 2013, laba bersih terendah sebesar $(-0,0020)$ dari total aset oleh PT Prima Alloy Steel Universal Tbk. tahun 2017 dan standar deviasi antara nilai tertinggi dan terendah sebesar 0,0967. Variabel independen kedua yaitu leverage dengan menggunakan alat ukur debt to asset ratio. Rata-rata perusahaan menggunakan total utang 0,3967 dari total aset. Total utang tertinggi sebesar 0,8809 oleh PT Jembo Cable Company Tbk. tahun 2013, total utang terendah sebesar 0,0837 oleh PT Semen Baturaja (Persero) Tbk. tahun 2014 dan standar deviasi antara nilai tertinggi dan terendah sebesar 0,1632 .

Variabel independen ketiga yaitu size dihitung dengan menggunakan logaritma natural aset. Ratarata ukuran perusahaan sebesar 21,7460 dari total aset. Ukuran perusahaan tertinggi sebesar 26,4124 dari total aset oleh PT Astra International Tbk. tahun 2017, ukuran perusahaan terendah sebesar 18,7117 dari total aset oleh PT Lionmesh Prima Tbk. tahun 2015 dan standar deviasi antara nilai tertinggi dan terendah sebesar 1,6559.

Variabel independen keempat yaitu intensitas aset tetap. Rata-rata intensitas asset tetap adalah sebesar 0,4234. Intensitas aset tetap tertinggi sebesar 0,8081 oleh PT Semen Baturaja (Persero) Tbk. tahun 2016, total aset tetap terendah sebesar 0,1001 oleh PT Delta Djakarta Tbk. tahun 2017 dan standar deviasi antara nilai tertinggi dan terendah sebesar 0,1610 .

Variabel independen kelima yaitu pertumbuhan penjualan Rata-rata pertumbuhan penjualan sebesar 0,0758. Pertumbuhan penjualan tertinggi sebesar 4,1873 oleh PT Jembo Cable Company Tbk. tahun 2013, pertumbuhan penjualan terendah sebesar (0,7599) oleh PT Semen Baturaja (Persero) Tbk. tahun 2015 dan standar deviasi antara nilai tertinggi dan terendah sebesar 0,6760 .

\section{Uji Asumsi Klasik}

Berdasarkan hasil dari uji multikolinearitas, VIF kurang dari 10 (dapat dilihat dari tabel 3). Oleh sebab itu, dapat disimpulkan bahwa data yang digunakan dalam penelitian ini tidak ada multikolinearitas. Berdasarkan tabel 3 diatas menunjukkan bahwa, maka data yang digunakan dapat digunakan untuk penelitian ini.

Tabel 3

Uji Multikolinearitas

\begin{tabular}{lrrrrr}
\hline & ROA & LEV & SIZE & IAT & GROWTH \\
\hline ROA & 1.0000 & -0.1043 & 0.1962 & -0.0957 & -0.0570 \\
LEV & -0.1043 & 1.0000 & 0.0240 & 0.2284 & 0.5877 \\
SIZE & 0.1962 & 0.0240 & 1.0000 & 0.2922 & -0.1808 \\
IAT & -0.0957 & 0.2284 & 0.2922 & 1.0000 & -0.5428 \\
GROWTH & -0.0570 & 0.5877 & -0.1808 & -0.5428 & 1.0000 \\
\hline
\end{tabular}

Sementara terkait heterokedastisitas, dapat dilihat pada tabel 4. Tabel tersebut menunjukkan bahwa nilai F-statistic adalah 1,5722. Nilai ini diatas 0,05 maka angka tersebut dapat disimpulkan bahwa data tersebut tidak ada heteroskeditas, maka data penelitian ini dapat digunakan untuk penelitian. 
Tabel 4

Uji Heterokedastisitas

\begin{tabular}{lrll}
\multicolumn{4}{l}{ Heteroskedasticity Test: Breusch-Pagan-Godfrey } \\
\hline \hline F-statistic & 1.5722 & Prob. F $(5,234)$ & 0.1687 \\
\hline \hline Obs*R-squared & 7.8007 & Prob. Chi-Square(5) & 0.1676 \\
Scaled explained SS & 95.8757 & Prob.Chi-Square(5) & 0.0000 \\
\hline
\end{tabular}

Sumber: Data diolah dengan Eviews 9

\section{Analisa Data}

Tabel dibawah adalah hasil uji hipotesis antara variable independen, variabel kontrol dan variabel dependen (tabel 4), sebagai berikut:

Tabel 5

Ringkasan Hasil Uji Hipotesis

\begin{tabular}{clccl}
\hline & \multicolumn{1}{c}{ Hipotesis } & Sig. & Koefisien & \multicolumn{1}{c}{ Hasil } \\
\hline H1 & $\begin{array}{l}\text { Profitabilitas berpengaruh positif } \\
\text { terhadap penghindaran pajak }\end{array}$ & 0,0001 & 1,0760 & Terdukung \\
H2 & $\begin{array}{l}\text { Leverage berpengaruh negatif } \\
\text { terhadap penghindaran pajak }\end{array}$ & 0,0259 & $-0,6570$ & Terdukung \\
H3 & $\begin{array}{l}\text { Ukuran perusahaan berpengaruh } \\
\text { positif terhadap penghindaran pajak }\end{array}$ & 0,3592 & 0,0181 & Tidak \\
H4 & $\begin{array}{l}\text { Intensitas aset tetap berpengaruh } \\
\text { negatif terhadap penghindaran pajak }\end{array}$ & 0,0923 & 0,4601 & $\begin{array}{l}\text { Tidak } \\
\text { Terdukung }\end{array}$ \\
H5 & $\begin{array}{l}\text { Pertumbuhan penjualan berpengaruh } \\
\text { positif terhadap penghindaran pajak }\end{array}$ & 0,0621 & 0,1353 & $\begin{array}{l}\text { Tidak } \\
\text { Terdukung }\end{array}$ \\
\hline
\end{tabular}

Berdasarkan tabel 4 diatas, dapat menunjukkan bahwa hipotesis pertama $\left(\mathrm{H}_{1}\right)$ terdukung yaitu secara positif profitabilitas berpengaruh terhadap penghindaran positif. Penelitian ini juga sejalan dengan penelitian sebelumnya yang di lakukan oleh Puspita \& Febrianti (2017) dan Dewinta \& Setiawan (2016). Namun, penelitian ini tidak sejalan dengan penelitian yang dilakukan oleh Cahyono, Andini, \& Raharjo (2016) menunjukkan tidak pengaruh antara profitabilitas terhadap penghindaran pajak.

Hasil penelitian ini membuktikan bahwa semakin tinggi profit sebuah perusahaan maka tingkat penghindaran pajak semakin tinggi. Hal tersebut karena profit perusahaan sangat mempengaruhi nilai pajak yang akan dibayarkan dan perusahaan berupaya untuk mencari celah untuk melakukan tindakan untuk meminimalkan biaya pajak. Perusahaan akan mengupayakan untuk memperkecil nilai pajak dengan memanfaatkan biaya depresiasi. Semakin efektif penggunaan aset tetap maka laba yang dihasilkan semakin banyak dan semakin produktif pula aset yang digunakan. Hal tersebut dapat menjadi pemicu bagi perusahaan untuk melakukan tindakan penghindaran pajak.
Berdasarkan pengujian hipotesis kedua menunjukkan leverage berpengaruh negative terhadap penghindaran pajak. Hali ini nilai signifikan sebesar 0,0259. Hal ini sejalan dengan hasil penelitian Dharma \& Ardiana (2016) tetapi tidak sejalan dengan penelitian Irianto, Sudibyo, dan Wafirli (2017) yang menunjuukan leverage tidak berpengaruh terhadap penghindaran pajak.

Hasil penelitian ini menunjukkan bahwa hipotesis kedua $\left(\mathrm{H}_{2}\right)$ terdukung yaitu secara negatif leverage terhadap penghindaran pajak. Hasil penelitian ini sama dengan penelitian yang dilakukan Dharma \& Ardiana (2016), tetapi tidak sejalan dengan penelitian Irianto, Sudibyo, \& Wafirli (2017) menunjukkan leverage tidak ada pengaruh sama sekali dengan penghindaran pajak.

Hasil penelitian ini membuktikan bahwa semakin tinggi hutang perusahaan maka semakin rendah tindakan manajemen melakukan penghindaran pajak Hal ini karena utang perusahaan mempengaruhi nilai beban bunga yang akan mengurangi nilai laba kena pajak perusahaan. Perusahaan yang tergolong besar cenderung menggunakan hutang dari pihak ketiga. Hal tersebut karena dana dari pihak ketiga yang dipinjamkan biasanya dengan nilai yang cukup besar. Sehingga perusahaan memiliki peluang untuk lebih memperluas usahanya. Namun, semakin besarnya sebuah perusahaan maka nilai laba yang dihasilkan semakin besar, sehingga pemanfaatan nilai bunga dari pinjaman pihak ketiga dapat dijadikan pengurang laba kena pajak perusahaan.

Hasil pengujian hipotesis ketiga $\left(\mathrm{H}_{3}\right)$ tidak terdukung. Penelitian ini sejalan. Penelitian ini sejalan dengan penelitian Cahyono, Andini, \& Raharjo (2016) dan Permata, Nurlaela, \& Mastoh W (2018) tetapi tidak sejalan dengan penelitian Irianto, Sudibyo, \& Wafirli (2017) dan Dewinta \& Setiawan (2016) menemukan bahwa ukuran perusahaan berpengaruh secara positif terhadap penghindaran pajak.

Hasil penelitian ini membuktikan bahwa besar kecilnya sebuah perusahaan tidak bisa dijadikan dasar dalam memperhitungkan tingkat penghindaran pajaknya. Hal tersebut karena perusahaan besar yang cenderung memiiki aset banyak belum tentu secara efektif menggunakan aset nya dalam menghasilkan laba tinggi yang akan mempengaruhi nilai pajak yang akan dibayarkan.

Penggunaan asset yang dilakukan secara terus menerus untuk menghasilkan produksi barang atau jasa yang diharpkan untuk menghasilkan laba yang tinggi. maka ketika perusahaan tidak menggunakan asset tetap secara efektif maka laba yang dihasilkan 
juga semakin berkurang sehingga laba yang rendah tersebut semakin berkurang sehingga laba yang rendah tidak dapat menjadi pemicu perusahaan untuk melakukan tindakan penghindaran pajak

Hasil pengujian hipotesis keempat $\left(\mathrm{H}_{4}\right)$ tidak terdukung. Penelitian ini sejalan dengan hasil penelitian Puspita \& Febrianti (2017) dan Adisamartha \& Noviari (2015) tetap tidak sejalan dengan penelitian Dharma \& Ardiana (2016) dan Muzakki \& Darsono (2015) yang menyatakan intensitas aset tetap berpengaruh negatif terhadap penghindaran pajak.

Hasil penelitian ini membuktikan bahwa semakin tinggi banyak aset tetap sebuah perusahaan tidak menjamin bahwa penghindaran pajak semakin tinggi. Hal ini bisa disebabkan karena perusahaan tidak terlalu mengutamakan investasi berupa aset tetap sehingga aset yang sedikit dan penggunaannya yang tidak efektif dalam menghasilkan laba, sehingga laba yang kecil tidak membuat perusahaan merasa harus mengeluarkan biaya yang lebih besar untuk pajaknya.

Hasil pengujian hipotesis kelima $\left(\mathrm{H}_{5}\right)$ tidak terdukung yaitu pengaruh pertumbuhan penjualan terhadap penghindaran pajak. Penelitian ini sejalan dengan hasil penelitian Permata, Nurlaela, \& Mastoh W (2018) dan tidak sejalan dengan penelitian Dewinta \& Setiawan (2016) dan Hidayat (2018) yang menunjukkan adanya pengaruh positif antara pertumbuhan penjualan terhadap penghindaran pajak.

Hasil penelitian ini membuktikan bahwa peningkatan penjualan dari periode sebelum ke periode sekarang tidak dapat dijadikan tolak ukur untuk menentukan tingkat penghindaran pajak. Hal ini karena semakin tinggi peningkatan penjualan perusahaan maka akan lebih mendapat perhatian dari petugas pajak. Sehingga perusahaan lebih waspada dalam melakukan manajemen pajak dan memperkecil tindakan untuk menghindari pajak.

Berdasarkan hasil uji hipotesis pertama menunjukkan bahwa profitabilitas berpengaruh positif terhadap penghindaran pajak. Hal ini terbukti dengan nilai signifikansi sebesar 0,0001 dengan tingkat signifikansi 5\%. Penelitian ini sejalan dengan hasil penelitian Puspita \& Febrianti (2017) dan Dewinta \& Setiawan (2016), tetapi tidak sejalan dengan penelitian Cahyono, Andini, \& Raharjo (2016) yang menunjukkan tidak ada pengaruh antara profitabilitas terhadap penghindaran pajak.

Hasil penelitian ini membuktikan bahwa semakin tinggi tingkat utang sebuah perusahaan maka semakin minim tindakan penghindaran pajak yang dilakukan. Hal ini karena utang perusahaan mempengaruhi nilai beban bunga yang akan mengurangi nilai laba kena pajak perusahaan.

Ukuran perusahaan berpengaruh positif terhadap penghindaran pajak

Berdasarkan hasil pengujian hipotesis ketiga menunjukkan bahwa ukuran perusahaan tidak berpengaruh terhadap penghindaran pajak. Hal ini dibuktikan dengan nilai signifikansi sebesar 0,3592 yang lebih besar dari tingkat signifikansi (5\%). Penelitian ini sejalan dengan penelitian Cahyono, Andini, \& Raharjo (2016) dan Permata, Nurlaela, \& Mastoh W (2018) tetapi tidak sejalan dengan penelitian Irianto, Sudibyo, \& Wafirli (2017) dan Dewinta \& Setiawan (2016) yang menyatakan ukuran perusahaan berpengaruh positif terhadap penghindaran pajak.

Hasil pengujian keempat menunjukkan bahwa intensitas asset tetap tidak berpengaruh terhadap penghindaran nilai signifikan sebesar 0,0923. Penelitian ini sejalan dengan hasil penelitian puspita \& Febrianti (2017) dan Adisamarha \& Novriari (2015) tidak sejalan dengan penelitian Dharma \& Ardiana (2016) dan Muzakki \& Darsono (2015) yang menyatakan intensias aset tetap berpengaruh negatif terhadap penghindaran pajak. Hasil penelitian ini membuktikan bahwa semakin tinggi banyak aset tetap sebuah perusahaan tidak menjamin bahwa penghindaran pajak semakin tinggi. Hal ini bisa disebabkan karena tidak efektifnya penggunaan aset tetap dalam menghasilkan laba, sehingga laba yang dihasilkan tidak menjadi pemicu perusahaan dalam meminimalkan biaya pajak perusahaan.

Berdasarkan hasil pengujian hipotesis kelima menunjukkan bahwa pertumbuhan penjualan tidak berpengaruh terhadap penghindaran pajak. Hal ini dibuktikan dengan nilai signifikan sebesar 0,0621. Penelitian ini sejalan dengan hasil penelitian permata, murlaela \& mastoh W (2018) dan tidak sejalan dengan penelitian Dewinta dan Setiawan (2016) dan Hidayat 2018) menunjuukan adanya pengaruh positif antara pertumbuhan penjulan terhadap penghindaran pajak. Hasil penelitian ini membuktikan bahwa peningkatan penjualan perusahaan dari periode lalu ke periode sekarang tidak bisa menjadi total ukur perusahaan dalam melakukan tindakan penghindaran pajak. 


\section{Kesimpulan dan Saran}

\section{Simpulan}

Beberapa kesimpulan yang dapat diambil dari hasil pengujian dalam penelitian ini sebagai berikut:

a. Terdapat pengaruh positif antara Profitabilitas terhadap penghindaran pajak. Artinya semakin tinggi profit sebuah perusahaan maka akan cenderung melakukan praktik penghindaran pajak.

b. Terdapat berpengaruh negatif antara Leverage terhadap penghindaran pajak. Artinya semakin besar tingkat hutang perusahaan maka praktik penghindaran pajaknya semakin kecil.

c. Tidak ada pengaruh antara ukuran perusahaan terhadap penghindaran pajak. Artinya besar kecilnya sebuah perusahaan tidak dapat dijadikan tolok ukur dalam upaya melakukan penghindran pajak.

d. Tidak ada pengaruh antara intensitas aset tetap terhadap penghindaran pajak. Artinya kepemilikan aset yang banyak tidak dapat mempengaruhi tindakan penghindaran pajak.

e. Tidak ada pengaruh antara pertumbuhan terhadap penghindaran pajak. Artinya peningkata $\mathrm{n}$ penjualan dari periode lalu ke periode sekarang tidak bisa dijadikan tolok ukur untuk menentukan penghindaran pajak. Hal itu disebabkan pertumbuhan penjualan yang tinggi belum tentu berpengaruh terhadap laba yang dihasilkan karena setiap periode juga menghasilkan harga pokok penjualan yang berbeda.

\section{Saran}

Terdapat beberapa saran untuk penelitian selanjutnya sebagai berikut:

a. Penelitian selanjutnya diharapkan dapat memperluas sampel, tidak hanya sebatas sektor manufaktur, namun menambah sampel pada seluruh sektor perusahaan di BEI.

b. Penelitian selanjutnya diharapkan dapat menambah rentang waktu yang lebih lama agar dapat menggambarkan efek langsung dari tax avoidance yang dilakukan perusahaan.

c. Penelitian selanjutnya dapat menambah alat ukur yang digunakan pada variabel penghindaran pajak (tax avoidance).

\section{Daftar Pustaka}

Adisamartha, I. P., \& Noviari, N. (2015). Pengaruh Likuiditas, Leverage, Intensitas Persediaan, dan Intensitas Aset Tetap pada Tingkat Agresivitas Wajib Pajak Badan. E-Jurnal Akuntansi Universitas Udayana, 973-1000.

Arianandini, P. W., \& Ramantha, I. W. (2018). Pengaruh Profitabilitas, Leverage, dan Kepemilikan Institusional pada Tax Avoidance. E-Jurnal Akuntansi Universitas Udayana, 2088-2116.

Basuki, A. T., \& Prawoto, N. (2016). Analisis Regresi Dalam Penelitian Ekonomi \& Bisnis : Dilengkapi Aplikasi SPSS \& EVIEWS. Depok: PT Rajagrafindo Persada.

Brigham, E. F., \& Houston, J. F. (2001). Manajemen Keuangan (2 ed.). Jakarta: Erlangga.

Cahyono, D. D., Andini, R., \& Raharjo, K. (2016). Pengaruh Komite Audit, Kepemilikan Institusional, Dewan Komisaris, Ukuran Perusahaan (Size), Leverage (DER), dan Profitabilitas (ROA) Terhadap Tindakan Penghindaran Pajak (Tax Avoidance). Journal of Accounting.

Darmadi, I. N. (2013). Analisis Faktor yang Mempengaruhi Manajemen Pajak Dengan Indikator Tarif Pajak Efektif. Simposium Nasional Akuntansi 17 Mataram, Lombok.

Darmawan, I. H., \& Sukartha, I. M. (2014). Pengaruh Penerapan Corporate Governance, Leverage, Return on Assets, dan Ukuran Perusahaan Pada penghindaran Pajak. E-Jurnal Akuntansi Universitas Udayana, 143-161.

Dewinta, I. A., \& Setiawan, P. E. (2016). Pengaruh Ukuran Penjualan, Umur Perusahaan, Profitabilitas, Leverage, dan Pertumbuhan Penjualan Terhadap Tax Avoidance. E-Jurnal Akuntansi Universitas Udayana, 1584-1613.

Dharma, I. S., \& Ardiana, P. A. (2016). Pengaruh Leverage, Intensitas Aset Tetap, Ukuran Perusahaan, dan Koneksi Politik Terhadap Tax Avoidance. E-Jurnal Akuntansi Universitas Udayana, 584-613.

Ghozali, I. (2016). Aplikasi Analisis Multivariatedengan Program IBM SPSS 23. Semarang: BPFE Universitas Diponegoro.

Goh, B. W., Lee, J., Lim, C. Y., \& Shevlin, T. (2013). The Effect of Corporate Tax Avoidance on the Cost of Equity. Research Collection School of Accountancy, 1-51.

Gujarati, D. N. (2012). Dasar-Dasar Ekonometrika, Edisi Lima, Buku Dua. Jakarta: Salemba Empat.

Hanafi, M. M., \& Halim, A. (2016). Analisis Laporan Keuangan (Kelima ed.). Yogyakarta: UPP STIM YKPN.

Hidayat, W. W. (2018). Pengaruh Profitabilitas, Leverage, dan Pertumbuhan Penjualan Terhadap Penghindaran Pajak: Studi Kasus Perusahaan Manufaktur di Indonesia. Jurnal Riset Manajemen dan Bisnis (JRMB) Fakultas Ekonomi UNIAT, 19-26. 
Horne, V., \& Wachowicz. (2013). Prinsip-Prinsip Manajemen Keuangan. Jakarta: Salemba Empat.

Irianto, B. S., Sudibyo, Y. A., \& Wafirli, A. (2017). The Influence of Profitability, Leverage, Firm Size and Capital Intensity Towards Tax Avoidance . International Journal of Accounting and Taxation , 33-41

Jensen, M. C., \& Meckling, W. H. (1976). Theory of The Firm: Managerial Behavior, Agency Cost and Ownership Structure. Journal of Financial Economics 3, 305-360.

Kasmir. (2014). Analisis Laporan Keuangan (Pertama ed.) Jakarta: PT Rajagrafindo Persada.

Kieso, D. E., Weygandt, J. J., \& Wardield, T. D. (2011). Intermediate Accounting. United States America: John Willey dan Sons.

Murhadi, W. R. (2013). Analisis Laporan Keuangan, Proyeksi dan Valuasi Saham. Jakarta: Salemba Empat.

Muzakki, M. R., \& Darsono. (2015). Pengaruh Corporate Social Responsibility dan Capital Intensity Terhadap Penghindaran Pajak. Diponegoro Journal of Accounting, 1-8.

Permata, A. D., Nurlaela, S., \& Mastoh W, E. (2018). Pengaruh Size, Age, Profitability, Leverage dan Sales Growth Terhadap Tax Avoidance. . Jurnal Akuntansi dan Pajak, 10-20.
Pohan, C. A. (2016). Manajemen Perpajakan Strategi Perencanaan Pajak dan Bisnis. Jakarta: PT Gramedia Pustaka Utama.

Puspita, D., \& Febrianti, M. (2017). Faktor-Faktor yang Memengaruhi Penghindaran Pajak Pada Perusahaan Manufaktur di Bursa Efek Indonesia. Jurnal Bisnis dan Akuntansi, 38-46.

Seftianne, \& Handayani, R. (2011). Faktor-Faktor yang Mempengaruhi Struktur Modal pada Perusahaan Publik Sektor Manufaktur. Jurnal Bisnis dan Akuntansi, 39-56.

Sugiyono. (2009). Metode Penelitian Kuantitatif, Kualitatifdan $R \& D$. Bandung: Alfabeta.

Watts, R. L., \& Zimmerman, J. L. (1986). Positive Accounting Theory. USA: Prentice-Hall.

Widarjo, W., \& Setiawan, D. (2009). Pengaruh Rasio Keuangan terhada Kondisi Financial Distress Perusahaan Otomotif. Jurnal Bisnis dan Akuntansi, Vol.11 No.2.

Widarjono, A. (2009). Ekonometrika Pengantar dan Aplikasinya (Ketiga ed.). Yogyakarta: Ekonisia.

Winarno, W. W. (2015). Analisis Ekonometrika dan Statistik dengan Eviews. Yogyakarta: UPP STIM YKPN. 